Personalidade Acadêmica Homenageada:

Carlos Aurélio Mota de Souza (Universidade Ibirapuera - UNIB)

\title{
A INTERVENÇÃO DO ESTADO NO TRATAMENTO DIFERENCIADO DAS MICRO E PEQUENAS EMPRESAS APLICADO NO MUNICÍPIO DE ARAUCÁRIA
}

\section{THE INTERVENTION OF THE STATE IN THE DIFFERENTIAL TREATMENT OF MICRO AND SMALL ENTERPRISES APPLIED IN THE MUNICIPALITY OF ARAUCÁRIA}

\section{ELIEZER CORDEIRO}

Presidente do Comitê Gestor das Microempresas e Empresas de Pequeno Porte de Araucária, Presidente de Comissão Permanente de Licitação de Compras e Serviços da Prefeitura Municipal de Araucária, Diretor de Desenvolvimento Econômico de Araucária, integrante do Grupo de Trabalho e Pesquisa de Acesso a Mercados à Micro e Pequena Empresa da Câmara Técnica de Pequenos Negócios do PróMetrópole(Curitiba e RMC), membro titular do Conselho do Plano Diretor de Araucária, membro do Conselho Municipal de Contribuinte de Araucária, Agente de Desenvolvimento Econômico de Araucária de acordo com a Lei Complementar 123/2006, membro do Comitê organizador do Programa de Desenvolvimento Econômico de Araucária - Avança Araucária. Graduando em Direito pela Faculdade Nacional de Educação e Ensino Superior do Paraná - FANEESP.

\section{OBJETIVOS DO TRABALHO}

$\mathrm{Na}$ busca por entender a posição do Estado diante da ordem econômica e financeira, tendo como referência a promulgação de leis que trouxeram ao ordenamento jurídico o tratamento diferenciado às micro e pequenas empresas no âmbito nacional a partir da Constituição Federal de 1988, interferindo nas atividades 


\section{Personalidade Acadêmica Homenageada:}

\section{Carlos Aurélio Mota de Souza (Universidade Ibirapuera - UNIB)}

econômicas e sociais. Para melhor compreensão do tema, será avaliada a experiência do Município de Araucária, estado do Paraná.

O objetivo principal é o acompanhamento da implementação de políticas públicas atribuídas à administração pública, na concretização das normas constitucionais, supralegais e infraconstitucionais, sob o aspecto de intervenção do Estado na ordem econômica.

\section{METODOLOGIA UTILIZADA}

A investigação se dará por método dedutivo, baseada em pesquisas qualitativas e quantitativas, com arrimo na evolução das micro e pequenas empresas do município de Araucária, bem como na melhoria do ambiente de negócios local em razão do tratamento diferenciado a ela concedido.

Por conseguinte, o desafio do direito será de instrumentalizar formas de garantir que o direito objetivo posto nas normas seja aplicado, para que normas sejam eficazes e não se tornem puramente programáticas ou inócuas.

\section{REVISÃO DE LITERATURA}

A Constituição Federal de 1988 ao abarcar em sua estrutura artigos com ênfase à ordem econômica e financeira, delimita o domínio do Estado, mesmo que de forma programática, mas bastante clara às suas divisas na ordem econômica e financeira.

Para Alexandre de Moraes": "O Direito Constitucional moderno ampliou as tradicionais dimensões da Constituição, incluindo, entre outras matérias, normas referentes à ordem econômica e financeira". O Art. 170 da Carta Magna, que dispõe sobre os limites para a atuação e o comportamento do Estado, em consonância com a ordem econômica e financeira ${ }^{2}$

\footnotetext{
${ }^{1}$ MORAES, Alexandre de. Direito constitucional. São Paulo: Atlas, 2018. p. 1130.

2 "A ordem econômica, fundada na valorização do trabalho humano e na livre iniciativa, tem por fim assegurar a todos existência digna, conforme os ditames da justiça social, observados os seguintes
} 


\section{Personalidade Acadêmica Homenageada:}

Carlos Aurélio Mota de Souza (Universidade Ibirapuera - UNIB)

Num mercado onde se tem a concentração de renda e domínio do mercado poderá haver o abuso do poder econômico, sendo relevante a dinâmica de um mercado com livre concorrência que propicie a ampliação da variedade e da qualidade dos produtos e serviços, com uma consequente diminuição dos preços.

O dispositivo constitucional visa assegurar este mercado mais competitivo com pequenas interferências do Estado na liberdade dos agentes econômicos, para o livre acesso e permanência de competidores no mercado.

Entretanto é importante deixar consignado que o mesmo texto constitucional que busca valorizar a livre iniciativa e o livre comércio, admite a intervenção do Estado para o desenvolvimento nacional sustentável, regulando o mercado e elevando a força do consumidor diante do fornecedor nesta relação de consumo, visando o bem comum.

A Emenda Constitucional no 06/1995, alterou a redação dos Arts. 170, IX, 176, $\S 1$ 1; revogou o art. 171, e criou o art. 246, na Constituição Federal, trazendo a inovação do tratamento diferenciado e favorecido as Micro e Pequenas empresas nacionais. Não basta se isso, o legislador tratou desta matéria em dispositivo supralegal, instituindo através da Lei Complementar 123/2006 o estatuto da Micro e Pequena Empresa.

O tratamento diferenciado e favorecido às Micro e pequenas empresas- MPEs nasce da necessidade de incrementar e desburocratizar a atividade empresarial no âmbito nacional. De acordo com o Anuário do Trabalho dos Pequenos Negócios do SEBRAE, em 2016 existiam no Brasil mais de 6,8 milhões de MPEs, responsável por mais de $54 \%$ (cinquenta e quatro por cento) dos empregos, o que justifica o tratamento diferenciado a estas empresas.

princípios: I - soberania nacional; II - propriedade privada; III - função social da propriedade; IV - livre concorrência; V - defesa do consumidor; VI - defesa do meio ambiente; VII - redução das desigualdades regionais e sociais; VIII - busca do pleno emprego; IX - tratamento favorecido para as empresas de pequeno porte constituídas, sob as leis brasileiras e que tenham sua sede e administração no país". (CONSTITUIÇÃO FEDERAL, 1988, art. 170). 


\section{Personalidade Acadêmica Homenageada:}

\section{Carlos Aurélio Mota de Souza (Universidade Ibirapuera - UNIB)}

No município de Araucária, Paraná, 93\% das empresas são $\mathrm{MPEs}^{3}$, sendo 4.812 Micros Empreendedores Individuais, 2.762 Micro Empresas e 283 Empresas de Pequeno Porte.

Com a promulgação do Estatuto da Micro e Pequena Empresa, e, com os estímulos e benefícios trazidos pela norma supralegal, espera que haja um fomento do mercado, criando empregos e gerando renda, assim também aumentando o consumo, condições fundamentais para o desenvolvimento econômico sustentável nacional.

Importa ressaltar que a Lei Complementar 123/2006, trouxe em seu bojo os ditames para que uma empresa se enquadre para credenciamento dos benefícios, e ainda o Regime especial de recolhimento de tributos - Simples Nacional, o tratamento diferenciado na participação em licitações públicas entre outros.

Este tratamento diferenciado, muito embora possa parecer uma interferência estatal que, a princípio, poderia trazer prejuízo à livre concorrência, uma vez que se amplia o benefício de certas empresas em detrimento de outras, busca-se regular o mercado protegendo as entidades que não têm condições de competir diretamente com as grandes empresas e, assim, tenta-se pôr em prática a efetiva liberdade de concorrência e iniciativa.

No âmbito do município de Araucária, foi redigida minuta pelo Comitê Gestor Municipal, que resultou na Lei Complementar Municipal 017/2018, sancionada em 14 de setembro de 2018, e tem em seu bojo como itens principais a desburocratização do processo público para obtenção de Alvará de Funcionamento e Localização, tanto provisório como o definitivo, inclusão das MPEs nas licitações públicas, acesso a crédito, acesso à justiça, entre outros temas.

\section{TÓPICOS CONCLUSIVOS}

No que tange a desburocratização verificada pela pesquisa em relação ao Município de Araucária, até o presente momento foi possível observar pela análise

\footnotetext{
3 JUNTA COMERCIAL DO PARANÁ. Disponível em: www.empresafacil.pr.gov.br. Acesso em: 17 out. 2018.
} 
Personalidade Acadêmica Homenageada:

Carlos Aurélio Mota de Souza (Universidade Ibirapuera - UNIB)

dos dados, uma significativa diminuição do tempo de espera para a obtenção de Alvará de funcionamento e localização, com a redução de tempo de espera de 30 dias para 24 horas, em relação ao provisório, e de 120 dias para 30 dias, para o definitivo.

Os próximos indicadores a serem medidos deverão se dar com relação à quantidade de empresas que no término do exercício fiscal migrarão o seu enquadramento, em razão do aumento ou diminuição do seu faturamento, e se é possível vincular esta alteração em face da implementação das políticas públicas protecionistas adotadas pelo Município de Araucária, comparando-se com o período anterior à sua adoção.

\section{REFERÊNCIAS}

ARAUCÁRIA. Lei Complementar Municipal no 017/2018: sancionada em 14 de setembro de 2018. Araucária, Paraná: 2018.

BRASIL. Constituição da República Federativa do Brasil: promulgada em 5 de outubro de 1988. Brasília: Senado Federal.

Lei Complementar no. 123 (Estatuto Nacional da Microempresa e da Empresa de Pequeno Porte) de 15 de dezembro de 2006. Brasília: 2006.

. Lei no. 8.078 (Código de Defesa do Consumidor) de 11 de setembro de 1990. Brasília: Congresso Nacional, 1990.

JUNTA COMERCIAL DO PARANÁ. Disponível em: www.empresafacil.pr.gov.br. Acesso em: 17 out. 2018.

MORAES, Alexandre de. Direito constitucional. 34. ed. São Paulo: Atlas, 2018.

SEBRAE. Anuário do trabalho nos pequenos negócios: 2016. 9.ed. São PauloSP: DIEESE, 2018 